\title{
A study on the vertical profile of bacterial DNA structure in the Puruogangri (Tibetan Plateau) ice core using denaturing gradient gel electrophoresis
}

\author{
Xinfang ZHANG, ${ }^{1,4}$ Tandong YAO, ${ }^{1,3}$ Lizhe AN, ${ }^{1,2}$ Lide TIAN, ${ }^{1,3}$ Shijian XU ${ }^{1,2}$ \\ ${ }^{1}$ Cold and Arid Regions Environmental and Engineering Research Institute, Chinese Academy of Sciences, \\ 260 Donggang West Road, Lanzhou 730000, China \\ E-mail: zhangxftop@163.com \\ ${ }^{2}$ School of Life Science, Lanzhou University, Lanzhou 730000, China \\ ${ }^{3}$ Institute of Tibetan Plateau Research, Chinese Academy of Sciences, Beijing 100029, China \\ ${ }^{4}$ Gansu Provincial Hospital, Lanzhou 730000, China
}

\begin{abstract}
The bacterial DNA structures at different depths in the Puruogangri (Tibetan Plateau) ice core $(83.45 \mathrm{~m})$ were investigated by the denaturing gradient gel electrophoresis (DGGE) DNA fingerprinting technique. DGGE profiles indicated that the bacterial species diversity in glacial ice is high, and indigenous species represented by common bands in all samples may grow on the glacial surface. Bacterial diversity, as estimated by Shannon indices (mean 2.91; SD 0.25; $n=13$ ), was comparable to that of soil habitats and had a positive correlation with $\mathrm{Ca}^{2+}$ concentration $(R=0.71$; $P<\mathbf{0 . 0 1})$, a good proxy of dust. This suggested that the soil ecosystem was the main source of bacteria in this glacier. The low similarity indices $(0-43 \%)$ were found between the ice-core samples, which corresponded to the episodic deposition under defined climatic conditions and low activity of microorganisms in glacial ice. The profiles of bacterial species composition in glacial ice may be a bioindicator of climatic changes or dating.
\end{abstract}

\section{INTRODUCTION}

Ice cores are long-term, chronological repositories of microorganisms. The assemblages of airborne microorganisms immured chronologically within glacial ice are species that were atmospheric constituents originating from a variety of ecological sources at defined ages in history (Priscu and Christner, 2004).

With the progress of biological techniques and the increase of interest in the diversity and survival mechanism of microorganisms in frozen samples, studies of diversity, viability and physiology of the organisms in glacial ice became feasible. Although viruses, bacteria, fungi, pollen grains and seeds have been identified in glacial ice (Abyzov, 1993; Dancer and others, 1997; Abyzov and others, 1998; Castello and others, 1999; Christner and others, 2000; Zhang and others, 2001), the detection, isolation and characterization of microorganisms from glaciers are still relatively novel enterprises.

A number of studies have focused on DNA diversity, bacterial recovery or longevity from glaciers (Christner and others, 2001; Zhang and others, 2001; Sheridan and others, 2003), but few attempts have been made to determine the structure of bacterial populations preserved in ice deposited under diverse environments, and there are no documented reports of the changes of the bacterial population profile at different depths of the ice core. However, how the structure of microbial populations entrapped in ice cores at defined climatic and environmental boundaries changed and how these changes are related to the corresponding environmental conditions are interesting questions (Castello and Rogers, 2005).

The denaturing gradient gel electrophoresis (DGGE) DNA fingerprinting technique offers a more rapid and comprehensive means to simultaneously survey various bacterial populations, allowing the comparison of total bacterial communities of different samples through pattern analysis, and at the same time describing the community structure intuitively. Since DGGE was introduced into microbial ecology by Muyzer and others (1993), many studies have been carried out to obtain outlines of the bacterial communities associated with environmental perturbations or seasonal, spatial and geographical variability (Ferris and others, 1996; Iwamoto and others, 2000; Riemann and others, 2000). Here, we examine the bacterial DNA profile of 13 selected Puruogangri (Tibetan Plateau) ice-core samples along its $83.45 \mathrm{~m}$ length by DGGE with the following three objectives: (1) to investigate the abundance and diversity of organisms in this sample and make comparisons with studies of geographically different ice cores and different habitats; (2) to evaluate changes in the microbial community structure along its length, and relations between the changes and environmental fluctuations; and (3) to describe what are the dominant indices in this glacier ice and how the organisms exist in situ.

\section{MATERIALS AND METHODS}

\section{Site feature}

The Puruogangri ice field $\left(33^{\circ} 44^{\prime}-34^{\circ} 04^{\prime} \mathrm{N}, 89^{\circ} 00^{\prime}-\right.$ $89^{\circ} 20^{\prime} \mathrm{E} ; 5970 \mathrm{~m}$ a.s.l.) is the largest glacier on the Tibetan Plateau, with a total area of $422.58 \mathrm{~km}^{2}$, and is located in the middle of the plateau on the western end of the Tanggula mountain range (Fig. 1). The ice field is surrounded by lakes and sand dunes that lap onto its margins, and the sand is most mobile in the spring. Its vertical relief facilitates the transportation of fragments of the sparse vegetation in the area to the top of the ice field (Yao, 2000). In October 2000, the average temperature on the glacier surface (6000 $\mathrm{m}$ a.s.I.) 
Table 1. Ice-core samples, depth, $\mathrm{Ca}^{2+}$ concentration, structural biodiversity $(H)$ and dominance indexes $(S)$ calculated from the digitized DGGE patterns shown in Figure 2

\begin{tabular}{crrrc}
\hline Sample No. & Depth & \multicolumn{1}{c}{$\mathrm{Ca}^{2+}$} & $H^{\prime}$ & $S$ \\
& $\mathrm{~m}$ & $\mathrm{ppb}$ & & \\
\hline 1 & & & & \\
\hline & 0.15 & 653.95 & 2.54 & 0.0873 \\
3 & 0.55 & 1784.23 & 3.11 & 0.0473 \\
4 & 1.64 & 2140.44 & 3.14 & 0.0484 \\
5 & 6.14 & 387.13 & 2.46 & 0.0987 \\
6 & 6.97 & 1345.00 & 2.99 & 0.0530 \\
7 & 10.86 & 736.42 & 2.91 & 0.0571 \\
8 & 13.88 & 1542.36 & 3.06 & 0.0494 \\
9 & 22.70 & 1074.09 & 2.48 & 0.1126 \\
10 & 31.53 & 1405.31 & 2.87 & 0.0457 \\
11 & 40.44 & 2584.99 & 3.17 & 0.0509 \\
12 & 71.13 & 2504.37 & 3.02 & 0.0524 \\
13 & 81.07 & 3587.34 & 3.08 & 0.0586 \\
& 83.45 & 2698.61 & 2.98 & 0.0511 \\
\hline
\end{tabular}

was $-14.6^{\circ} \mathrm{C}$ and the highest temperature was $-3.6^{\circ} \mathrm{C}$, whereas the temperature at $80 \mathrm{~m}$ in the borehole was $-7^{\circ} \mathrm{C}$.

\section{Sampling}

In October 2000, an ice core was drilled from the flat part $\left(33^{\circ} 54^{\prime} 57^{\prime \prime} \mathrm{N}, 89^{\circ} 06^{\prime} 59^{\prime \prime} \mathrm{E} ; 6000 \mathrm{~m}\right.$ a.s.l.) of the Puruogangri ice field, extending to $83.45 \mathrm{~m}$ below the surface. Without thawing, sections of the ice core were sealed in plastic tubes which were then placed inside aluminum-covered cardboard tubes. These were immediately transported to the Cold and Arid Regions Environmental and Engineering Research Institute, Chinese Academy of Sciences, and kept in an ice-core storeroom $\left(-20^{\circ} \mathrm{C}\right)$ prior to sampling. Thirteen samples with a vertical length of about $15 \mathrm{~cm}$ were selected at different depths, as shown in Table 1.

To aseptically sample the ice core for DNA extraction, the samples were manipulated in an ultraviolet (UV)-sterilized positive-pressure laminar-flow hood and placed in a biologically clean room according to Christner and others (2005). The $5 \mathrm{~mm}$ outermost layer of ice was scraped with a newly autoclaved sawtoothed knife, and the inner $5 \mathrm{~mm}$ was sliced with another autoclaved sawtoothed knife. Sections of the scraped ice cores were held with sterile forceps within the laminar-flow hood and completely rinsed with $-20^{\circ} \mathrm{C}$ $0.2 \mu \mathrm{m}$ filtered $95 \%$ ethanol, and then rinsed with $500 \mathrm{~mL}$ of $4{ }^{\circ} \mathrm{C}$ sterile, deionized water (Milli-Q Element System, Millipore, USA). The remaining ice was placed in sterile containers with a lid and allowed to thaw completely at $4^{\circ} \mathrm{C}$. The control core was processed and melted following an identical protocol to those of the samples. Ten $\mathrm{mL}$ of the newly melted subsamples prepared as above were used for the analysis of ions using an ion chromatography system (DX 600, Dionex Corp., USA). A control core constructed with Milli-Q-purified redistilled water was processed by methods identical with those of the sample.

\section{Extraction of genomic DNA}

The melted ice samples $(\sim 200 \mathrm{~mL})$ were filtered with a $0.2 \mu \mathrm{m}$ pore-size autoclaved filter (diameter $25 \mathrm{~mm}$; Millipore). Total DNA was extracted from bacterial cells trapped on the filter, which was suspended in $1 \mathrm{~mL}$ of TE buffer $(\mathrm{pH}$ 8.5), supplemented with $0.13 \mathrm{~g}$ of lysozyme and $20 \mu \mathrm{L}$

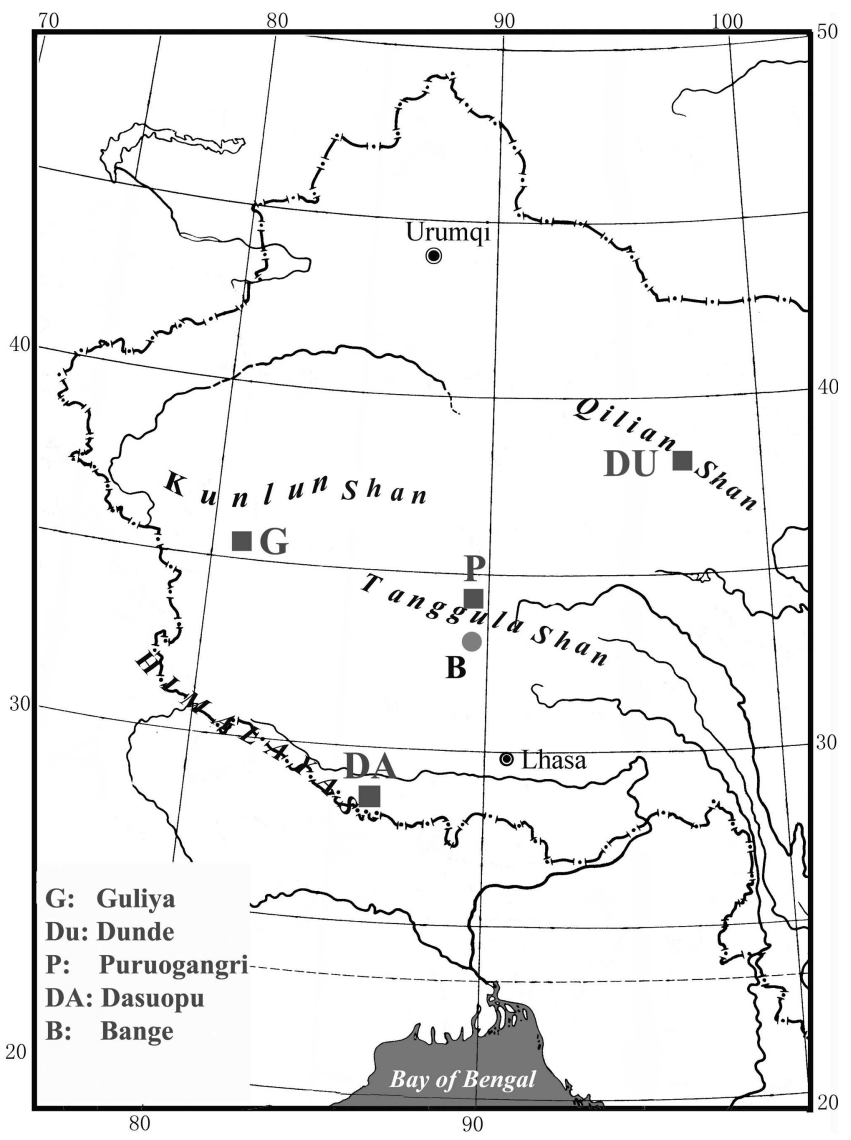

Fig. 1. Map of the location of the sampling region.

proteinase $\mathrm{K}\left(20 \mathrm{mg} \mathrm{mL}^{-1}\right)$, and incubated at $37^{\circ} \mathrm{C}$ for $30 \mathrm{~min}$. After that, the resulting suspensions were mixed with $80 \mu \mathrm{L}$ SDS $(20 \%)$ and incubated at $65^{\circ} \mathrm{C}$ for 2 hours. DNA was extracted with equal volumes of phenol-chloroform-isoamyl alcohol $(25: 24: 1, \mathrm{vol} / \mathrm{vol} / \mathrm{vol})$ and chloroform-isoamyl alcohol (24:1, vol/vol). The supernatant fluid was transferred to another Eppendorf tube and precipitated with 0.7 volume of cold isopropanol and 0.1 volume of $3 \mathrm{M}$ sodium acetate $(\mathrm{pH} 5.8)$ at $-20^{\circ} \mathrm{C}$ overnight, and centrifuged at $>16000 \mathrm{~g}$ for $30 \mathrm{~min}$ at $4^{\circ} \mathrm{C}$. The DNA pellets were washed with $70 \%$ cold ethanol and dried. Finally, the dried pellets were resuspended in a TE buffer and pooled to give a final volume of $30 \mu \mathrm{L}$.

\section{PCR and DGGE}

DGGE was performed as described by Muyzer and others (1993). PCR amplification was performed in a thermocycler (Icycler, Bio-RAD) in a $25 \mu \mathrm{L}$ reaction mixture. The V3 hypervariable region of bacterial $16 \mathrm{~S}$ rDNA fragments was amplified by using primers 357F-GC (5'CGCCCGCCGCGCGCGGCGGGCGGGGCGGGGGCACGGGGGGCCTACGGGAGGCAGCAG-3') and 518R (5'-GTATTACCGCGGCTGCTGG-3') as the PCR primers (Muyzer and others, 1993). Each amplification reaction mixture $(25 \mu \mathrm{L})$ consisted of $0.5 \mathrm{U}$ of Ex Taq DNA polymerase (Takara Shuzo, Otsu, Japan), $50 \mu \mathrm{g}$ of genomic DNA solution, $2.5 \mu \mathrm{L}$ of $10 \times$ PCR buffer, each primer at a concentration of $0.25 \mu \mathrm{M}$, and a mixture containing deoxynucleoside triphosphate at a concentration of $100 \mu \mathrm{M}$ in a tube. A touchdown program (Muyzer and others 1993; Ogino and others, 2001) was implemented as follows: firstly there was an initial denaturation at $94^{\circ} \mathrm{C}$ for $5 \mathrm{~min}$ followed by 30 cycles at 


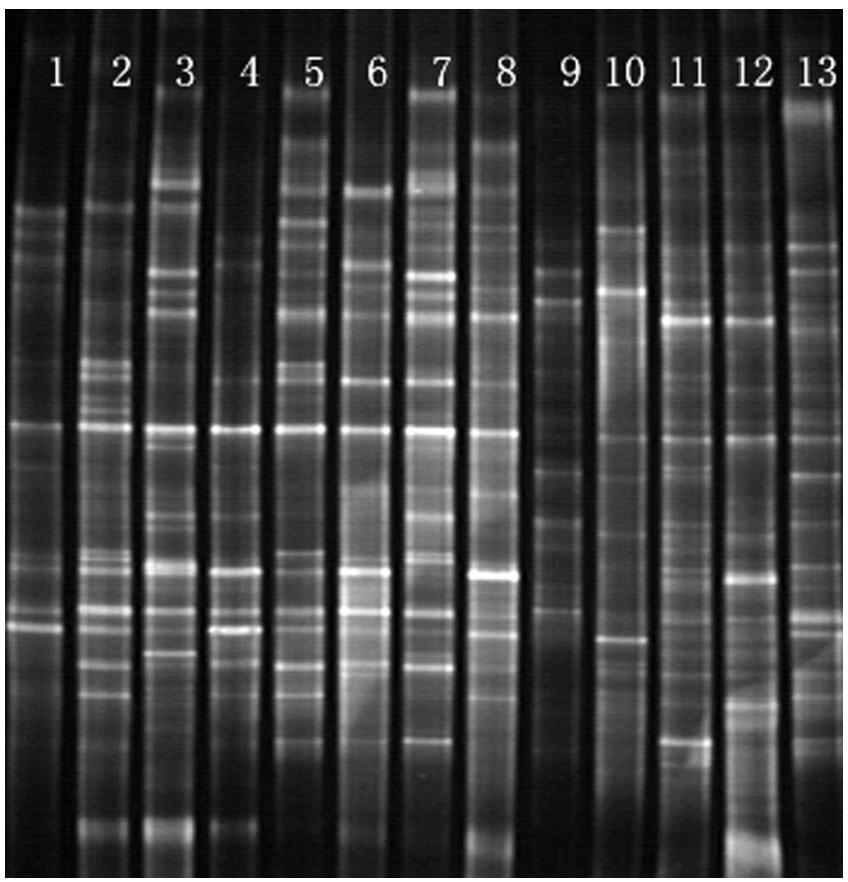

Fig. 2. DGGE analysis (8\% polyacrylamide gel, $30-60 \%$ denaturant gradient) of PCR-amplified 16S rDNA gene V3 fragments from icecore samples of different depths. Lane numbers correspond to sample numbers indicated in Table 1.

$94^{\circ} \mathrm{C}$ for $1 \mathrm{~min}$, an annealing temperature for $1 \mathrm{~min}$, and $72^{\circ} \mathrm{C}$ for $1 \mathrm{~min}$, and finally the reaction mixture was kept at $72^{\circ} \mathrm{C}$ for $7 \mathrm{~min}$. During the reaction cycle, the annealing temperature was decreased by $1^{\circ} \mathrm{C}$ from 65 to $56^{\circ} \mathrm{C}$ every second cycle in the first 20 cycles. The annealing temperature was $55^{\circ} \mathrm{C}$ in the last 10 cycles. The amplified product was analyzed by electrophoresis on $1.5 \%$ agarose gels and quantified by UV spectrophotometer (UV 7501, Techcomp) for DGGE; 250 ng of purified amplicons was used. DGGE was performed using a D-Code system (Bio-Rad Laboratories, Inc., Hercules, CA).

PCR products were separated on a $1.5 \mathrm{~mm}$ thick vertical gel containing $8 \%$ (wt/vol.) polyacrylamide and a linear gradient of the denaturants urea and formamide, increasing from $30 \%$ at the top of the gel to $60 \%$ at the bottom. Here, $100 \%$ denaturant is defined as $7 \mathrm{M}$ urea and $40 \%$ ( $\mathrm{vol} / \mathrm{vol}$ ) formamide. DGGE was conducted with $0.5 \times$ TAE buffer $(1 \times$ TAE buffer is $0.04 \mathrm{M}$ Tris base, $0.02 \mathrm{M}$ sodium acetate and $10 \mathrm{~mm}$ EDTA $(\mathrm{pH} 7.4))$ at a constant voltage of $35 \mathrm{~V}$ at $60^{\circ} \mathrm{C}$ for 18 hours. The gel was stained with SYBR Green-I (Molecular Probes, Eugene, OR, USA) and photographed on a UV transilluminator (UVP, Bioimaging system).

\section{Statistical analysis of DGGE banding patterns}

To determine the information content of the banding patterns in terms of their structural diversity, the DGGE profile was analyzed in the following two ways:

1. The similarities of all possible pairs of gel tracks were calculated, and then a cluster analysis of the matrix of similarity values and visualization in a dendrogram were performed. Bacterial population similarity between samples was compared using the Dice-Sorensen similarity index (Pielou, 1966) with MultiVariate Statistical Package (MVSP) version 3.12h (GeoMem, Blairgowrie, UK). The
Dice coefficient SD $=2 j /(a+b)$, where $j$ is the number of bands common to both samples, $a$ is the number of bands in sample $A$, and $b$ is the number of bands in sample B. This number is then multiplied by 100 to obtain the percentage similarity. A value of 0 indicates that the samples are completely different, whereas a value of 100 indicates that they are identical.

2. Bacterial diversity was estimated with the ShannonWeaver index $\left(H^{\prime}\right)$ from the DGGE banding pattern of the samples, which made it possible to determine changes in species diversity. Then the Shannon-Weaver index was performed with the Labworks 4.0 software package (UVP Bioimaging system) based on the number and relative intensities of bands on a gel strip. For banding profile comparisons, it was assumed that single DGGE bands contained a single taxon. The Shannon-Weaver index of general diversity, $H^{\prime}$ (Shannon and Weaver, 1963), was calculated using the following function:

$$
H^{\prime}=-\sum P_{\mathrm{i}} \log P_{\mathrm{i}}
$$

where $P_{\mathrm{i}}$ is the importance probability of the bands in a track. $H^{\prime}$ was calculated on the basis of the bands on the gel tracks using the intensity of the bands as judged by peak heights in the densitometric curves. The importance probability $P_{\mathrm{i}}$ was calculated as:

$$
P_{\mathrm{i}}=\frac{n_{i}}{N^{\prime}}
$$

where $n_{i}$ is the height of a peak and $N$ is the sum of all the peak heights of the bands in the densitometry profile.

The Simpson index of dominance, $S$ (Simpson, 1949), was calculated using the following function:

$$
S=\sum P_{\mathrm{i}}^{2}
$$

\section{RESULTS}

The DGGE profiles of the bacterial DNA from ice-core samples taken at different depths are shown in Figure 2. The number, precise position and intensity of the bands reflect the number, species and relative abundance of dominant rDNA types in the samples and thus allow a comparison of bacterial DNA structures with each other. Each lane of the DGGE profile contained many bands, numbering approximately 17-29 (Fig. 2), which indicated that a great diversity of bacterial species has evolved in the Puruogangri ice core, but the patterns of diversity did not seem to be related to sample depth. The band patterns appeared to be different for the different depths. However, some bands appear to be common to all samples of different depths, and several intensive bands were clearly visible in some samples, which demonstrated that the dominant species are not limited to one or two.

Dendrograms were constructed from the matrix of similarity values of the DGGE banding patterns based on band existence (Fig. 3). Differences between the samples along the length were higher, as indicated by the low similarity indices $(0-43 \%)$. Three distinct clusters were recognized, which corresponded to the microbial DNA structure in each of the three periods when snow was deposited under different environmental conditions. The DGGE profile of samples 1-6 clustered together; samples 7 , 8, 10, 11, 12 and 13 clustered into another major group; and sample 9 clustered separately. The closer sections of the 


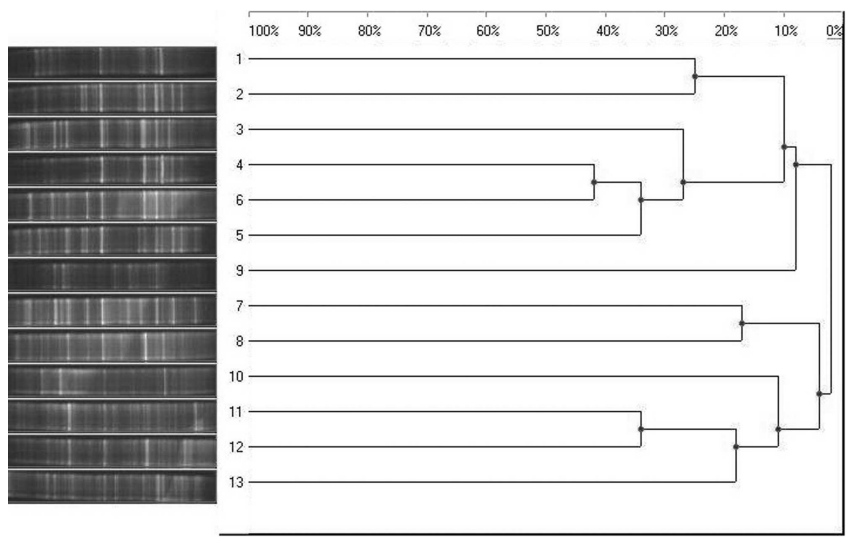

Fig. 3. Dendrogram derived from DGGE analysis of the bacterial DNA structure on the basis of the Dice's coefficient of similarity with the clustering algorithm. Lane numbers correspond to sample numbers indicated in Table 1.

ice core show higher similarity of bacterial DNA structure, and the highest similarity was found between samples 4 and $6(43 \%)$.

The concentration of dominance $(S)$ and the general index of biodiversity $\left(H^{\prime}\right)$ were calculated on the basis of the number and relative intensities of bands on a gel track (Table 1). Biodiversity as well as concentration of dominance varied. The Shannon index $\left(H^{\prime}\right)$ fluctuated within the range 2.46-3.17 (mean 2.91; SD 0.25; $n=13$ ). These results indicated bacterial species diversity in the ice core was high and fluctuated periodically, with three peaks in values along the whole length (Fig. 4). The concentration of dominance (mean $0.062 ;$ SD $0.022 ; n=13$ ) fluctuated within the range $0.047-0.112$. A negative correlation $(R=0.91 ; P<0.01)$ was found between diversity index and concentration of dominance (Fig. 4).

Concentrations of $\mathrm{Ca}^{2+}, \mathrm{Na}^{+}, \mathrm{Mg}^{2+}$ and $\mathrm{K}^{+}$at 13 increasing depth samples were investigated, and the variation in trends of $\mathrm{Ca}^{2+}$ concentration (mean $1.7 \times 10^{3}$; SD $\left.0.9 \times 10^{3} ; n=13\right)$ coincides with those of $\mathrm{Na}^{+}, \mathrm{Mg}^{2+}$ and $\mathrm{K}^{+}$(data not shown). A significant, positive correlation $(R=0.71 ; \quad P<0.01)$ was found between $H^{\prime}$ and $\mathrm{Ca}^{2+}$ concentration (Fig. 4).

\section{DISCUSSION AND CONCLUSIONS}

There have been many studies of bacterial diversity in ice cores using both culture-dependent and culture-independent methods. However, this is the first attempt to apply a DGGE DNA fingerprinting technique to study changes of bacterial DNA structure in an ice core from a non-polar ice core.

DGGE was introduced into microbial ecology to obtain an overview of the structural diversity of microbial communities (Muyzer and others, 1993). It is based on the separation of ribosomal gene sequences directly amplified from community DNA by using conserved primers on a denaturing gel according to their melting point. DGGE analysis with similarity and diversity algorithms proved to be a very powerful tool to monitor changes in the structure of the microbial community (Ferris and Ward, 1997; Eichner and others, 1999; Iwamoto and others, 2000). This procedure allowed one for the first time to
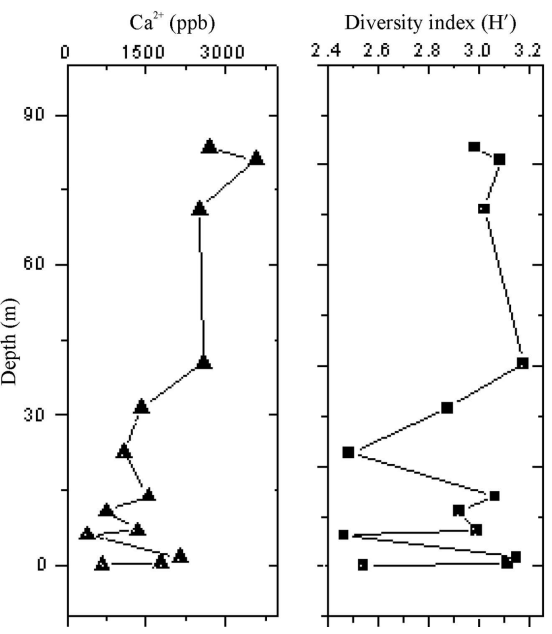

Dominance index $(\mathrm{S})$

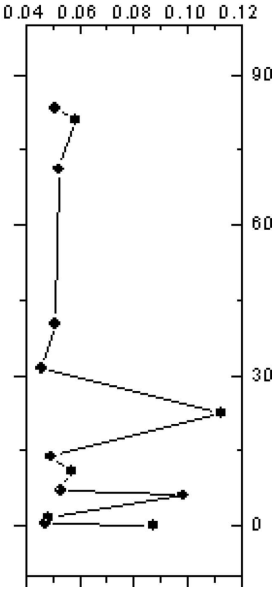

Fig. 4. Vertical profiles of $\mathrm{Ca}^{2+}$ concentration, Shannon index $\left(H^{\prime}\right)$ and dominance index $(S)$ in Puruogangri ice core.

directly identify the presence and relative abundance of different species and to profile microbial populations in both a qualitative and a semi-quantitative way. In this study, we investigated the changes in the bacterial DNA structure of the Puruogangri ice core by DGGE, and the relationship between bacterial diversity and $\mathrm{Ca}^{2+}$ concentration was also explored.

DGGE profiles indicated that bacterial species diversity is high in the Puruogangri ice core. The same result was verified by genomic DNA amplification and the recovery of viable bacteria in the Tibetan Plateau glacier (Zhang and others, 2002, 2003; Xiang and others, 2004). In general, icecore samples from non-polar, low-latitude, high-altitude glaciers contain a greater number, as well as more diversity, of bacterial species than those from polar ice. This can most probably be attributed to the proximity of major biological ecosystems (Abyzov and others, 1998; Priscu and others, 1999; Christner and others, 2000; Zhang and others, 2003). It can be hypothesized that the monsoon, local and global environmental conditions and surrounding ecosystems contributing biological particles to a particular air mass influence the concentration and diversity of airborne microorganisms (Christner and others, 2003; Segawa and others, 2005; Xiang and others, 2005). Puruogangri glacier is surrounded by lakes and sand dunes, which might contribute to the higher bacterial diversity in this glacier. Increased microbial deposition occurred in parts of the glacier that were contiguous to environments that supply airborne rock grains and soils (Christner and others, 2000), which served to transport and protect attached microorganisms. In addition, no relationship was perceived between DGGE pattern and depth, which probably implied that the microorganisms were deposited in the glacier episodically under diverse climatic conditions and at different historical times. This testified that perennial ice was a long-term, chronological repository of microbial assemblages corresponding to prevailing climate and environment conditions (Priscu and Christner, 2004; Castello and Rogers, 2005).

The commonality of some intensive bands in all samples (Fig. 2) may suggest that the corresponding bacterium was an endemic species and that it grew on the glacial surface. Christner and others (2003) found cryoconite holes might serve as biological refuges that, on glacial melting, can 
repopulate the local environments. However, the fact that these bacteria were only detected in a specific sample also suggests that they were occasionally supplied from the atmosphere and were not indigenous members of the snow microbiota in this region. In addition, several intensive bands were observable in some lanes (Fig. 2), which probably implied that the psychrophilic bacterial species having adapted to the unique habitat were not limited to one or two.

Community diversity is a key concept in ecology, and its quantification is fundamental for analyzing such phenomena as succession, colonization and response to disturbances. Changes in bacterial diversity of ancient organisms from an ice core can be used to formulate correlations between microbial distributions and environmental characteristics (climatic conditions, volcanism, etc.) at each of the time points (Castello and Rogers, 2005). Here we applied the Shannon index (Shannon and Weaver, 1963), based on the number and intensity of DGGE bands, to reflect the changes in bacterial diversity within the microbial assemblages in the ice core with no need for cultivation. The biodiversity index $\mathrm{H}^{\prime}$ and concentration of dominance combines the relative abundance of species and the total specific richness, thus reflecting the distribution of the dominance amongst the major species present in the samples studied. High $H^{\prime}$ values (mean $=2.91$ ) revealed that the bacterial diversity in the Puruogangri ice core was high but the variability was not related to the sample depth (Fig. 4). The lower index of dominance (Table 1) compared to another active community (Ampe and Miambi, 2000) is further evidence that microbial assemblages in glacial ice are a relatively silent world. Interestingly, a significantly negative correlation between $H^{\prime}$ and $S$ values was found (Fig. 4). This reflects the inherent dynamics of the bacterial community.

Noticeably, the Shannon index, $H^{\prime}$, displayed a positive correlation with the $\mathrm{Ca}^{2+}$ concentration (Fig. 4), which is a good proxy of the dust in the ice core from the Tibetan Plateau (Sheng and others, 1999; Wu and others, 2004). Variations of $\mathrm{Ca}^{2+}$ concentration are generally related to climatic changes: high $\mathrm{Ca}^{2+}$ concentration periods coincided with cold periods, and low $\mathrm{Ca}^{2+}$ concentration periods with warm periods (Sheng and others, 1999; Wu and others, 2004; Wang and others, 2006). Thus we conclude that more bacterial species are deposited in the glacier during cold periods, and fewer during warm periods. Logically, the intensified atmospheric circulation during cold climatic periods helped increase the concentration of airborne dust particles. Therefore, more organisms attached to the macroparticles were moved along the glacier surface during cold periods. Such conditions also decreased desiccation and increased the likelihood of bacterial survival. Moreover, dust particles protected microorganisms and influenced the amount as well as the physiological state of the microbes in ice (Priscu and others, 1998; Christner and others, 2000). For example, dust may form a cryoconite hole on a glacier, as it absorbs solar radiation and promotes melting of the ice beneath it, where the activities of algae and bacteria might be supported by photosynthesis and bacterial decomposition of old algae and other organic particles (Takeuchi and others, 2001, 2003). The results of this investigation indicated that the dust content might be more vital than other factors in determining bacterial species diversity in the Puruogangri glacial ice.
Studies indicated the bacterial diversity index $\left(H^{\prime}\right)$ in other habitats, the potential originating sources of microbes entrapped in the Puruogangri ice core, was varied. The Shannon index ranged from 3.72-4.44 in horticultural soil of southern Italy to 2.13 in an Italian agricultural soil and 2.87 in a Belgian soil (Andreoni and others, 2004; Crecchio and others, 2004). It ranged from 1.20 to 1.34 in Biwa lake (Japan) sediment (Koizumi and others, 2003) and from 0.887 to 1.271 in a North Sea marine environment (David, 2004). Shannon index analysis of the DGGE pattern revealed that the bacterial DNA diversity in the Puruogangri ice core was higher, ranging from 2.46 to 3.17 (mean 2.91; SD 0.25; $n=13$ ). The index value in the Puruogangri ice core is comparative to that of soil. This may imply that the microorganisms in the Puruogangri glacier mainly originated from a soil ecosystem, which is consistent with the result derived by $\mathrm{Ca}^{2+}$ analysis.

Another notable point is that periodic fluctuation of the Shannon index of bacterial DNA structure was observed. This probably reflected a cycle of climatic changes (Fig. 4). Unfortunately, due to the lack of climate analysis and dating data, we cannot elicit a precise relationship between bacterial DNA diversity and climatic factors or geologic events in a specific time frame in the Puruogangri ice core. But following an interdisciplinary perspective could be promising to verify the changes of climate.

Clustering analysis performed here demonstrated the percentage similarity between bacterial assemblages in the ice core. The closer sections of ice core showed higher resemblance in bacterial DNA structure (Fig. 3), which may be attributed to the fact that the variation of climate and corresponding environment was a gradual process. Parallel climatic conditions support similar vegetation. Therefore, the microorganisms transported to the glacier from distant sources by a defined monsoon were relatively similar at longer timescales (Priscu and others, 1998). Additionally, with the change of climatic and environmental conditions, the pattern of indigenous bacteria growing in the unique habitat of a glacial surface could shift gradually (Segawa and others, 2005). This might also account for the higher resemblance of bacterial population in closer sections of the ice core. Furthermore, there was less similarity found between the DGGE patterns of the bacterial structure (Fig. 3). The limited percentage similarity $(0-15 \%)$ between the bacterial community of sea-ice samples was reported as well (Brown and Bowman, 2001). However, the similarity between the bacterial community is high in other habitats where the bacterial community is active and shifting (Murray and others, 1998; Ampe and Miambi, 2000). As discussed below, the low similarity might reflect the episodic deposition of airborne microorganisms and low activity of bacteria in glacial ice.

We performed DGGE to show the bacterial DNA structure in a Puruogangri ice core. Using the ShannonWeaver index of diversity in combination with cluster analysis of the DGGE banding patterns, we were able to describe the bacterial structure and monitor the responses of bacterial structure to environmental changes. Bacterial species diversity is high in Puruogangri glacier ice, and the dust content is one key determining factor. Furthermore, the Shannon index based on the DGGE pattern of bacterial assemblages in glacial ice is a bio-indicator of climatic changes. More cultivation work and molecular analyses are required for high-altitude glacier habitats in which the microbial diversity still remains largely unstudied. 


\section{ACKNOWLEDGEMENTS}

We thank S. Rogers, J. Priscu and E. Mosley-Thompson for reviewing the manuscript and providing constructive comments, and X.J. Zhang for valuable assistance with DGGE analysis. We acknowledge the editorial assistance of P. Mayes. We thank members of the 2000 Puruogangri ice field expedition for their hard work in the field. This study was funded jointly by the National Science Foundation of China (40121101), the Knowledge Innovation Project of the Chinese Academy of Sciences (KZCX1-1-02), National Basic Research program of China (grant No. 2005CB422004) and the Science and Technology Department Foundation of China (2001CCB00300).

\section{REFERENCES}

Abyzov, S.S. 1993. Microorganisms in the Antarctic ice. In Friedmann, E.I., ed. Antarctic microbiology. New York, WileyLiss, Inc., 265-295.

Abyzov, S.S., I.N. Mitskevich and M.N. Poglazova. 1998. Microflora of the deep glacier horizons of central Antarctica. Microbiology, 67(4), 451-458.

Ampe, F. and E. Miambi. 2000. Cluster analysis, richness and biodiversity indexes derived from denaturing gradient gel electrophoresis fingerprints of bacterial communities demonstrate that traditional maize fermentations are driven by the transformation process. Int. J. Food Microbiol., 60(1), 91-97.

Andreoni, V., L. Cavalca and M.A. Rao. 2004. Bacterial communities and enzyme activities of PAHs polluted soils. Chemosphere, 57(5), 401-412.

Brown, M.V. and J.P. Bowman. 2001. A molecular phylogenetic survey of sea-ice microbial communities (SIMCO). FEMS Microbiol. Ecol., 35(3), 267-275.

Castello, J.D. and S.O. Rogers. 2005. Life in Ancient Ice. Princeton, NJ, Princeton University Press.

Castello, J.D. and 7 others. 1999. Detection of tomato mosaic tobamovirus RNA in ancient glacier ice. Polar Biol., 22(11), 207-212.

Christner, B.C., E. Mosley-Thompson, L.G. Thompson, V. Zagorodnov, K. Sandman and J.N. Reeve. 2000. Recovery and identification of viable bacteria immured in glacial ice. Icarus, 144(2), 479-485.

Christner, B.C., E. Mosley-Thompson, L.G. Thompson and J.N. Reeve. 2001. Isolation of bacteria and 16S rDNAs from Lake Vostok accretion ice. Environ. Microbiol., 3(9), 570-577.

Christner, B.C., E. Mosley-Thompson, L.G. Thompson and J.N. Reeve. 2003. Bacterial recovery from ancient glacial ice. Environ. Microbiol., 5(5), 433-436.

Christner, B.C., J.A. Mikucki, C.M. Foreman, J. Denson and J.C. Priscu. 2005. Glacial ice cores: a model system for developing extraterrestrial decontamination protocols. Icarus, 174(2), 572-584.

Crecchio, C., A. Gelsomino and R. Ambrosoli. 2004. Functional and molecular responses of soil microbial communities under differing soil management practices. Soil Biol. Biochem., 36(11), 1873-1883.

Dancer, S.J., P. Shears and D.J. Platt. 1997. Isolation and characterization of coliforms from glacial ice and water in Canada's High Arctic. J. Appl. Microbiol., 82(5), 597-609.

David, C.G. 2004. The effect of an acute copper exposure on the diversity of a microbial community in North Sea sediments as revealed by DGGE analysis - the importance of the protocol. Mar. Pollut. Bull. 49(6), 504-513.

Eichner, C.A., R.W. Erb, K.N. Timmis and I. Wagner-Dobler. 1999. Thermal gradient gel electrophoresis analysis of bioprotection from pollutant shocks in the activated sludge microbial community. Appl. Environ. Microb., 65, 102-109.
Ferris, M.J. and D.M. Ward. 1997. Seasonal distributions of dominant $16 \mathrm{~S}$ rRNA-defined populations in a hot spring microbial mat examined by denaturing gradient gel electrophoresis. Appl. Environ. Microb., 63(4), 1375-1381.

Ferris, M.J., G. Muyzer and D.M. Ward. 1996. Denaturing gradient gel electrophoresis profiles of $16 \mathrm{~S}$ rRNA-defined populations inhabiting a hot spring microbial mat community. Appl. Environ. Microb., 62(2), 340-346.

Iwamoto, T. and others. 2000. Monitoring impact of in situ biostimulation treatment on groundwater bacterial community by DGCE. FEMS Microbiol. Ecol., 32(2), 129-141.

Koizumi, Y., H. Kojima and M. Fukui. 2003. Characterization of depth-related microbial community structure in lake sediment by denaturing gradient gel electrophoresis of amplified $16 \mathrm{~S}$ rDNA and reversely transcribed $16 \mathrm{~S}$ rRNA fragments. FEMS Microbiol. Ecol., 46(2), 147-157.

Murray, A.E. and 6 others. 1998. Seasonal and spatial variability of bacterial and archaeal assemblages in the coastal waters near Anvers Island, Antarctica. Appl. Environ. Microb., 64(7), 2585-2595.

Muyzer, G., E.C. de Waal and A.G. Uitterlinden. 1993. Profiling of complex microbial populations by denaturing gradient gel electrophoresis analysis of polymerase chain reaction-amplified genes coding for $16 \mathrm{~S}$ rRNA. Appl. Environ. Microb., 59(3), 695-700.

Ogino, A., H. Koshikawa, T. Nakahara and H. Uchiyama. 2001. Succession of microbial communities during a biostimulation process as evaluated by DGGE and clone library analyses. J. Appl. Microbiol., 91(4), 625-635.

Pielou, E.C. 1966. The measurement of diversity in different biological collections. J. Theor. Biol., 13(1), 131-144.

Priscu, J.C. and B.C. Christner. 2004. Earth's icy biosphere. In Bull, A.T., ed. Microbial diversity and bioprospecting. Washington DC, American Society for Microbiology, 130-145.

Priscu, J.C. and 9 others. 1998. Perennial Antarctic lake ice: an oasis for life in a polar desert. Science, 280(5372), 2095-2098.

Priscu, J.C. and 11 others. 1999. Geomicrobiology of subglacial ice above Lake Vostok, Antarctica. Science, 286(5447), 2141-2144.

Riemann, L., G.F. Steward and F. Azam. 2000. Dynamics of bacterial community composition and activity during a mesocosm diatom bloom. Appl. Environ. Microbiol., 66(2), 578-587.

Segawa, T., K. Miyamoto, K. Ushida, K. Agata, N. Okada and S. Kohshima. 2005. Seasonal change in bacterial flora and biomass in mountain snow from the Tateyama Mountains, Japan, analyzed by $16 \mathrm{~S}$ rRNA gene sequencing and real-time PCR. Appl. Environ. Microb., 71(1), 123-130.

Shannon, C.E. and W. Weaver. 1963. The mathematical theory of communication. Urbana, IL, University of Illinois Press.

Sheng, W., T. Yao and Y.F. Li. 1999. Variation of $\mathrm{Ca}^{2+}$ within the Guliya ice core and its climatic significance. J. Glaciol. Geocryol, 21(1), 19-21.

Sheridan, P.P., V.I. Miteva and J.E. Brenchley. 2003. Phylogenetic analysis of anaerobic psychrophilic enrichment cultures obtained from a Greenland glacier ice core. Appl. Environ. Microbiol., 69(4), 2153-2160.

Simpson, E.H. 1949. Measurement of diversity. Nature, 163(4148), 688.

Takeuchi, N., S. Kohshima, T. Shiraiwa and K. Kubota. 2001. Characteristics of cryoconite (surface dust on glaciers) and surface albedo of a Patagonian glacier, Tyndall Glacier, Southern Patagonia Icefield. Bull. Glaciol. Res., 18, 65-69.

Takeuchi, N., S. Kohshima and T. Segawa. 2003. Effect of cryoconite and snow algal communities on suface albedo on maritime glaciers in south Alaska. Bull. Glaciol. Res., 20, 21-27.

Wang, N., T. Yao, L.G. Thompson and M.E. Davis. 2006. Strong negative correlation between dust event frequency and air temperature over the northern Tibetan Plateau reflected by the Malan ice-core record. Ann. Glaciol., 43 (see paper in this volume). 
Wu, G.J., T. Yao and L.G. Thompson. 2004. Microparticle record in the Guilya ice core and its comparison with polar records since the last interglacial. Chinese Sci. Bull., 49(9), 607-611.

Xiang, S.R. and 8 others. 2004. Bacterial diversity in Malan ice core from the Tibetan Plateau. Folia Microbiol., 49(3), 269-275.

Xiang, S., T. Yao, L. An, B. Xu and J. Wang. 2005. 16 S rRNA sequences and differences in bacteria isolated from the Muztag Ata glacier at increasing depths. Appl. Environ. Microbiol., 71(8), 4619-4627.
Yao, T. 2000. Puruogangri ice field was discovered in the middle of Tibetan Plateau. J. Glaciol. Geocryol., 22(1), 1-2. [In Chinese.]

Zhang, X., T. Yao, X. Ma and N. Wang. 2001. Analysis of the characteristics of microorganisms packed in the ice core of the Malan Glacier, Tibet. Sci. China D, 44(suppl.), 165-170.

Zhang, X., T. Yao and X. Ma. 2002. Microorganisms in a high altitude glacier ice in Tibet. Folia Microbiol., 47(3), 241-245.

Zhang, X., X. Ma, T. Yao and G. Zhang. 2003. Diversity of $16 \mathrm{~s}$ rDNA and environmental factor influencing microorganisms in Malan ice core. Chinese Sci. Bull., 48(11), 1146-1151. 